\title{
According to Candidate Teachers Views Classroom Management Problems of Teachers in Traditional and Technology-supported Classrooms
}

\author{
Said Taş \\ Faculty of Education, Süleyman Demirel University, Turkey
}

Copyright $(2017$ by authors, all rights reserved. Authors agree that this article remains permanently open access under the terms of the Creative Commons Attribution License 4.0 International License

\begin{abstract}
In this research, it is aimed to investigate classroom management problems of middle school $6^{\text {th }}$ and $7^{\text {th }}$ grade teachers in traditional and technology-supported classrooms and differences between them. For this purpose the opinions of the students in the $4^{\text {th }}$ grade of Primary Education Department in Faculty of Education of Süleyman Demirel University have been taken. In data analysis, t- test was used by calculating the arithmetic mean. As a result of the research it has been found that technology-supported classrooms are more aesthetic than traditional classrooms, but lighting is insufficient in technology-supported classrooms, teachers do not change the methods and techniques they use during the course in both traditional and technology-supported classrooms, the use of technology in classrooms provides teachers with help in managing the time, teachers in both traditional and technology-supported classrooms prefer standing at the same point but teachers in technology-supported classrooms can motivate students more easily and the use of technology makes no difference in the frequency of undesired behaviors out of the course.
\end{abstract}

Keywords Classroom Management, Educational Technologies, Technology-supported Classrooms

\section{Introduction}

Technology has an important place in our daily life as an indispensable part of our age. Significant developments in science and technology in recent years have affected the societies and their structures, and necessitated changes in numerous fields in societies. Societies have begun to restructure according to the developments in technology. Effects of technology have been observed very quickly especially in the areas such as structure of state, health and business world. In the $21^{\text {st }}$ century, in which it is not possible to avoid from the effects of technology, educational systems and educational institutions have been affected by these developments. Therefore, making changes in education has become a necessity.

With rapid changes in technology, the use of educational technology has become widespread in educational institutions. First, computers took part in school managers' rooms, then entered into the educational environment with computer laboratories and after that, it has become widespread in classrooms [1]. With interactive boards, one of the educational technologies; the substantiality of educational environments has increased positively every passing day. Today, educational technologies have become indispensable for classroom environments, and classes have got rid of classical structures and have become classes that have more educational equipment.

All these changes in technology also change the role of the teacher in the classroom. At the present time, a teacher is a counselor showing learners how to learn, what to learn, where to learn and where to use the things they learn; rather than relaying them the information. Although technology has come to the fore, it can never take the place of a teacher. Hence, educational technologies are used as a tool rather than a purpose. Improvements in educational technologies have affected educational environments and educational programs, besides changing the educational tools and classroom environments; in this way, it has brought a new dimension. [2; $3 ; 4 ; 5]$.

The use of tools in education is undeniably important because the effect of tools in education is quite excessive. Tools have become and will continue to become the handmaid of teachers in the classrooms and [6]. Educational environments, which formerly included only books, black board, pictures, overhead projectors and cinematographs [5], have shown up with different dimensions along with the technology. Especially with the entrance of computers and interactive boards into educational environments, tools have improved more. Visual elements and audial elements have created multimedia by combining with each other. Thus 
technology has started to increase its existence in classroom environments. There are many benefits of use of technology in the classroom environment. Some of these benefits can be expressed as that it makes learning concrete, ensures permanent learning, makes students active in learning, makes classroom environments enjoyable and amusing, decreases monotony, provides teachers with advantage in time management, motivates the students for lessons, makes teaching more efficient, provides teachers with highly important support in terms of practice, enables bringing the outer happenings into the classroom environment. $[7 ; 6 ; 8$; $3]$.

Besides all these educational benefits of using technology in classrooms, it is also beneficial for classroom management. Classroom management is the first step of educational management. It is important to regulate classroom management for an effective education. Classroom management is composing an environment which provides a proper education and regulating the process by using classroom sources effectively [9].

To be able to mention about the effects of technology on classroom management, dimensions of classroom management should be examined. Başar [9] mentions about five dimensions of classroom management;

The first dimension of classroom management is physical organization of classroom environment. In order to be able to provide effective learning and classroom management, physical properties in the classroom must be suitable and sufficient [10]. Behavioral change defined as education takes place in proper environments. Each variable related with physical environment can support education or obstruct it as well. The effect of physical properties in the classroom can change depending on the arrangement, the way of usage and the appearance [9]. Arranging learning-teaching environments in the first place is very important to be able to make given knowledge long lasting and permanent and transform it into behavior by internalizing. The arrangement of environments, which has become more complicated with the entrance of technology into the education environments, will improve the quality of education and help reach the purposes.

The second dimension of classroom management is managing the planning and programming activities. A teacher should know how to prepare effective plans and programs to be an effective classroom manager [11]. Plans and programs are very important for technology-supported environments, too. Teachers should not be passive; rather they should be active in the arrangement of technologic environments. If a teacher cannot arrange teaching methods and equipment which are suitable for technological environment, $\mathrm{s} / \mathrm{he}$ is going to have problems about managing the learning environment [5]. A Teacher should execute her/his plan in an order in the classroom. In order to do so, applications should be tried by the teacher in advance. Otherwise problems may arise in educational environment; there may be loss of time and undesired situations may be experienced. Pre-arranging and predetermining the educational activities, sources, the process, the equipment, characteristics of students will enable the educational services to be more effective. The third dimension of classroom management is time management. In classroom management it is highly important for teachers to use the time efficiently. A teacher should use the time well to be able to teach well and to be a good classroom manager. Wasted time cannot be replaced with a new one, and there is no turning back. Because of that, purposes should be chosen wisely, and time should be managed carefully to reach these purposes [12]. Especially in the technology-supported environments time should be managed well. Teachers should avoid wasting time trying to fix a problem faced while using the technology, and they should arrange the time in accordance with the lesson schedule. Teachers should be able to consume the time by producing.

The fourth dimension of classroom management is the relationship layout of the classroom. In-class relations are effective to form positive learning environment. Teacher-student and student-student interactions, determining classroom rules and infusing these rules into students, applications concerning the facilitation of classroom life constitute relationship layouts [9]. Education is an interaction process. The tool of this interaction is communication. Therefore, communication process is the essential requirement for education [13]. It is not possible to manage without communication. In that case, a successful manager is expected to use the intricacies of communication art very well. [14]. In the technology-supported environments equipment may affect students' attention in communication both positively and negatively. In the technology-supported environments changes between student-student and teacher-student interactions are inevitable. By means of technology, teachers should be able to reach students and have contact with them both in and out of the classroom. In addition, teachers should have communicative skills as well that can affect students as much as technology-supported environments. For this reason, teachers should increase the ratio of effect on the relationship arrangement in technology-supported environments.

The fifth dimension of classroom management is behavior arrangement. This dimension consists of making the classroom environment able to provide desired behavior, making the classroom climate positive, estimating problems beforehand, making students obey the classroom rules, changing the undesirable behaviors. Besides giving information in the classroom environment, teachers make students gain desired behaviors. In order to do so, teachers should exhibit model behaviors in the classroom environment [9]. In the technology-supported environments , the frequency of facing with undesired behaviors between the teacher and students. Because, having more intimacy with technology causes problems in human relations. Therefore, it has become a necessity for both teachers and students to know what they should be cautious for while 
using the technology.

There are many sources of problems encountered in the dimensions mentioned above in traditional and technology-supported classes. Some of these are development characteristics, mental sufficiency, student success, student motivation; physical situation of school, structure of relationships, inconsistency in rules, attitude of management, using the same teaching methods and techniques, not being able to communicate with students, not being able to use equipment efficiently, approaches to students' behaviors $[9 ; 15]$.

At the present time, physical structure of classrooms, success levels of students, teaching methods and techniques of teachers and classroom equipment have changed. These changes have affected the classroom management problems and caused changes

Aim of The Research In this research, it is aimed to determine the classroom management problems of teachers, teaching $6^{\text {th }}$ and $7^{\text {th }}$ grade students at middle schools, in terms of physical organization, plans and programs, time management, relationship layout and behavior arrangement dimensions of classroom management in traditional and technology-supported classrooms and to determine differences about classroom management problems between these two groups, according to candidate teachers' views.

In the direction of this general aim, sub objectives are determined as;

According to candidate teachers' views,

1. What are the classroom management problems of middle school $6^{\text {th }}$ and $7^{\text {th }}$ grade teachers in traditional and technology-supported classrooms in terms of physical organization dimension of classroom management?

2. What are the classroom management problems of middle school $6^{\text {th }}$ and $7^{\text {th }}$ grade teachers in traditional and technology-supported classrooms in terms of plans and programs dimension of classroom management?

3. What are the classroom management problems of middle school $6^{\text {th }}$ and $7^{\text {th }}$ grade teachers in traditional and technology-supported classrooms in terms of time management dimension of classroom management?

4. What are the classroom management problems of middle school $6^{\text {th }}$ and $7^{\text {th }}$ grade teachers in traditional and technology-supported classrooms in terms of relationship layout dimension of classroom management?

5. What are the classroom management problems of middle school $6^{\text {th }}$ and $7^{\text {th }}$ grade teachers in traditional and technology-supported classrooms in terms of behavior arrangement dimension of classroom management?

6. Is there any difference between the classroom management problems of middle school $6^{\text {th }}$ and $7^{\text {th }}$ grade teachers in traditional and technology-supported classrooms in terms of physical organization, plans and programs, time management, relationship layout and behavior arrangement dimensions of classroom management?

\section{Method}

\section{Research Model}

This study was designed in the general survey model based on the quantitative data. Numerical data such as numbers and measurements are called quantitative data and analysis using these numbers and values is called quantitative data analysis [16]. Survey models are research approaches that aim to describe past or present situations as they exist, without changing them. The object and the individual that are the issues of the research are evaluated and described within their existing conditions [17].

\section{Population and Sample}

Candidate teachers studying at Süleyman Demirel University Faculty of Education in the 2016-2017 school year constitute the population of the research. Süleyman Demirel University Faculty of Education Primary Education Department $4^{\text {th }}$ grade students constitute the sample of the research. Students were asked to evaluate $6^{\text {th }}$ and $7^{\text {th }}$ grade teachers, by the given scale, at schools they went for practicum and made observation for the lesson of teaching practice in spring semester 2016-2017 education year. These schools were Isparta merkez Yedi Şehitler, Bağlar, Nazmiye Demirel, Ülkü, Nazmi Toker, Iyaş, Gülistan, Kadir Boylu, ITO Şehit Mustafa Gözütok Middle Schools. In line with this purpose, questionnaires were conducted to 82 students and 79 of these questionnaires have been used as valid. The constituted measuring instrument was applied to 38 classrooms which technology was not used and 41 classrooms which technology was used. The research sample is bounded with $6^{\text {th }}$ and $7^{\text {th }}$ grade teachers because $5^{\text {th }}$ grade is the first grade of middle school and $8^{\text {th }}$ grade students are mostly trying to prepare for examination of passing from primary education to secondary education (teog).

\section{Data Collection and Analysis}

In the research, the data collection instrument developed by Özata [18] has been used by taking related expert opinions rearranging it according to the aim of the research. The reliability of the data collection instrument is tested as $r$ $=0.92$. The data collection tool consists of two parts. In the first part, there exists a general information concerning if the teacher uses a technological instrument or not, in the second part, there are questions related with the dimensions of classroom management. Four Point Likert-type scales have 
been used to collect the data.

SPSS 15 packet program has been used to analyze the data. For classroom management problems in traditional classrooms and technology-supported classrooms, the arithmetic mean of the factors have been taken and then ranked. Independent samples t-test has been used to analyze whether there is a significant difference between classroom management problems in two groups. In the analysis of the data, the range of points that can explain the level of efficiency of classroom management problems has been determined because the answers given by the students are from the four Point Likert-type scales.

\section{Findings and Interpretations}

Findings and comments about first sub problem "according to candidate teachers' views, the classroom management problems of middle school $6^{\text {th }}$ and $7^{\text {th }}$ grade teachers in traditional and technology-supported classrooms in terms of physical dimension of classroom management".

Table 1. The classroom management problems in classrooms without technology (traditional classrooms) in terms of "physical arrangement dimension" of classroom management.

\begin{tabular}{|c|c|c|c|}
\hline $\begin{array}{c}\text { Lighting conditions of classroom is proper } \\
\text { for education. }\end{array}$ & 38 & 3,45 & 0,68 \\
\hline $\begin{array}{c}\text { Cleaning of class is supplied. } \\
\text { The class is at the ideal temperature. }\end{array}$ & 38 & 2,47 & 1,09 \\
\hline The ventilation of class is sufficient. & 38 & 2,36 & 1,02 \\
\hline The noise level in the class is normal. & 38 & 2,26 & 0,92 \\
\hline Equipment in class is sufficient. & 38 & 2,21 & 0,99 \\
\hline The appearance of class is aesthetic. & 38 & 2,15 & 1,17 \\
\hline
\end{tabular}

At Table 1, in traditional classrooms, lighting conditions of classroom is always proper for education $(\bar{X}=3,45)$. Temperature $(\bar{X}=2,36)$, ventilation $(\bar{X}=2,31)$ and noise level $(\bar{X}=2,26)$ of classrooms seem to be sufficient sometimes. According to the results, in traditional classrooms equipment number is insufficient $(\bar{X}=2,21)$ and the classroom is never aesthetic $(\bar{X}=2,15)$. In traditional classrooms there is no problem in terms of lighting, ventilation, temperature and noise level but there are problems in terms of number of equipment and classroom appearance.

Table 2. The classroom management problems in technology-supported classrooms in terms of "physical arrangement dimension" of classroom management

\begin{tabular}{|c|c|c|c|}
\hline & N & Mean & SD \\
\hline Equipment in class is sufficient. & 41 & 3,07 & 0,64 \\
\hline The ventilation of class is sufficient. & 41 & 2,97 & 0,79 \\
\hline The appearance of class is aesthetic. & 41 & 2,92 & 0,78 \\
\hline The noise level in the class is normal. & 41 & 2,65 & 0,61 \\
\hline Cleaning of class is supplied. & 41 & 2,58 & 0,64 \\
\hline The class is at the ideal temperature. & 41 & 2,65 & 0,59 \\
\hline $\begin{array}{c}\text { Lighting conditions of classroom is proper } \\
\text { for education. }\end{array}$ & 41 & 1,65 & 0,91 \\
\hline
\end{tabular}

At Table 2, it is understood that in terms of physical conditions, classes are generally aesthetic $(\bar{X}=2,92)$ and adequate in terms of equipment $(\bar{X}=3,07)$ in technology-supported classrooms. Classroom ventilation $(\bar{X}=2,97)$, noise level $(\bar{X}=2,65)$, temperature $(\bar{X}=2,65)$ seem to be generally sufficient. However, lighting conditions of classrooms are never proper for education $(\bar{X}=1,65)$. The number of equipment is enough in technology-supported classrooms and thus classrooms seem more aesthetic. Some problems occur in the level of illumination because the projection equipment and the interactive boards are used in the technology-supported classrooms. Size of the windows, arrival angle of the light and insufficiency of curtains may be the source of the problem.

Findings and comments about the second sub problem "according to candidate teachers' views, the classroom management problems of middle school $6^{\text {th }}$ and $7^{\text {th }}$ grade teachers in traditional and technology-supported classrooms in terms of plans and programs dimension of classroom management".

Table 3. The classroom management problems in classrooms without technology (traditional classrooms) in terms of "plans and programs dimension" of classroom management

\begin{tabular}{|c|c|c|c|}
\hline & N & Mean & SD \\
\hline $\begin{array}{c}\text { The teacher plans classroom activities in } \\
\text { advance. }\end{array}$ & 38 & 2,55 & 1,00 \\
\hline $\begin{array}{c}\text { The teacher makes equipment ready before } \\
\text { starting the course. }\end{array}$ & 38 & 1,84 & 0,88 \\
\hline $\begin{array}{c}\text { The teacher changes method and techniques } \\
\text { used in classroom. }\end{array}$ & 38 & 1,74 & 0,67 \\
\hline
\end{tabular}

When traditional classrooms are examined in terms of plans and programs dimension, results show that the teacher usually plans classroom activities in advance $(\bar{X}=2,55)$. In traditional classrooms the teacher sometimes makes equipment ready before starting the course $(\bar{X}=1,84)$ but rarely changes method and techniques used in classroom $(\bar{X}=1,74)$. The fact that the traditional classes are in a uniform structure may cause the teachers not to use any methods other than classical methods.

Table 4. The classroom management problems in technology-supported classrooms in terms of "plans and programs dimension" of classroom management

\begin{tabular}{|c|c|c|c|}
\hline & $\mathbf{N}$ & Mean & SD \\
\hline $\begin{array}{c}\text { The teacher plans classroom activities in } \\
\text { advance. }\end{array}$ & 41 & 2,78 & 0,85 \\
\hline $\begin{array}{c}\text { The teacher makes equipment ready before } \\
\text { starting the course. }\end{array}$ & 41 & 2,34 & 0,53 \\
\hline $\begin{array}{c}\text { The teacher changes method and } \\
\text { techniques used in classroom. }\end{array}$ & 41 & 1,95 & 0,50 \\
\hline
\end{tabular}

It is found that in technology-supported classrooms teachers sometimes change the methods and techniques they use instead of using the same methods and techniques $(\bar{X}=1,95)$. As it has been observed in traditional classrooms, teachers plan classroom activities in advance $(\bar{X}=2,78)$ and make equipment ready before starting the course $(\bar{X}=2,34)$. But teachers slightly change the methods and techniques used in the classroom. 
Findings and comments about third sub problem "according to candidate teachers' views, the classroom management problems of middle school $6^{\text {th }}$ and $7^{\text {th }}$ grade teachers in traditional and technology-supported classrooms in terms of time dimension of classroom management".

Table 5. The classroom management problems in classrooms without technology (traditional classrooms) in terms of "time management dimension" of classroom management

\begin{tabular}{|c|c|c|c|}
\hline $\begin{array}{c}\text { The teacher can use time effectively during } \\
\text { the course. }\end{array}$ & 38 & Nean & SD \\
\hline $\begin{array}{c}\text { The teacher can use course equipment } \\
\text { sufficiently and effectively. }\end{array}$ & 38 & 2,28 & 0,94 \\
\hline $\begin{array}{c}\text { The teacher can provide vitality during the } \\
\text { course, does not bore students. }\end{array}$ & 38 & 2,00 & 0,77 \\
\hline $\begin{array}{c}\text { Classroom environment is an environment } \\
\text { that students want to spend most of their } \\
\text { time. }\end{array}$ & 38 & 1,89 & 0,89 \\
\hline
\end{tabular}

According to Table 5 in traditional classrooms teachers sometimes cannot use time $(\bar{X}=2,36)$ and equipment $(\bar{X}=2,28)$ sufficiently and effectively. The findings show that the students can get bored $(\bar{X}=2,00)$ because the teachers cannot provide vitality during the course, and also classroom environment can be seen as an environment that students don't want to spend most of their time $(\bar{X}=1,89)$.

Table 6. The classroom management problems in technology-supported classrooms in terms of "time management dimension" of classroom management

\begin{tabular}{|c|c|c|c|}
\hline & N & Mean & SD \\
\hline $\begin{array}{c}\text { The teacher can use time effectively during } \\
\text { the course. }\end{array}$ & 41 & 3,29 & 0,60 \\
\hline $\begin{array}{c}\text { The teacher can use course equipment } \\
\text { sufficiently and effectively. }\end{array}$ & 41 & 3,24 & 0,76 \\
\hline $\begin{array}{c}\text { The teacher can provide vitality during the } \\
\text { course, does not bore students. }\end{array}$ & 41 & 3,02 & 0,72 \\
\hline $\begin{array}{c}\text { Classroom environment is an environment } \\
\text { that students want to spend most of their } \\
\text { time. }\end{array}$ & 41 & 2,80 & 0,81 \\
\hline
\end{tabular}

It seems that teachers are sufficient in terms of time management in technology-supported classrooms. It has been found that in technology-supported classrooms teachers can use course equipment sufficiently and effectively $(\bar{X}=3,29)$ and can use time effectively during the course $(\bar{X}=3,24)$. Since in technology-supported classrooms teachers can use course equipment sufficiently and effectively, they can provide vitality during the course, and this does not bore students.

Findings and comments about the second sub problem "according to candidate teachers' views, the classroom management problems of middle school $6^{\text {th }}$ and $7^{\text {th }}$ grade teachers in traditional and technology-supported classrooms in terms relationship layout dimension of classroom management".

Research results show that in traditional classrooms teachers usually walk all over the classroom $(\bar{X}=2,68)$ and use their voice as everyone can hear them in the classroom $(\bar{X}=2,57)$. According to Table 7 teachers avoid using body language $(\bar{X}=1,97)$ and multidirectional communication with students $(\bar{X}=1,84)$ in traditional classrooms. It seems that in traditional classrooms teachers have difficulty about motivating students $(\bar{X}=1,73)$ and attracting students attention to the course $(\bar{X}=1,92)$ and therefore, students behave $\operatorname{shy}(\bar{X}=2,60)$.Teachers do not consider individual differences of students adequately $(\bar{X}=1,71)$ and avoid prompting students to make group work $(\overline{\mathrm{X}}=2,00)$. As a result of these situations, teachers cannot make students to participate in the lessons $(\bar{X}=2,23)$.

Table 7. The classroom management problems in classrooms without technology (traditional classrooms) in terms of "relationship layout dimension" of classroom management

\begin{tabular}{|c|c|c|c|}
\hline & N & Mean & SD \\
\hline $\begin{array}{c}\text { The teacher is walking all over the } \\
\text { classroom. }\end{array}$ & 38 & 2,68 & 0,99 \\
\hline Students behave shy. & 38 & 2,60 & 1,10 \\
\hline $\begin{array}{c}\text { The teacher uses her/his voice as everyone } \\
\text { can hear in the classroom. }\end{array}$ & 38 & 2,57 & 0,97 \\
\hline $\begin{array}{c}\text { The teacher gives the students the right to } \\
\text { speak. }\end{array}$ & 38 & 2,36 & 1,05 \\
\hline $\begin{array}{c}\text { The teacher makes eye contact with } \\
\text { students. }\end{array}$ & 38 & 2,00 & 0,92 \\
\hline $\begin{array}{c}\text { The teacher can provide the participation of } \\
\text { the students. }\end{array}$ & 38 & 2,23 & 0,81 \\
\hline $\begin{array}{c}\text { The teacher stands at the same point in the } \\
\text { classroom and does not move. }\end{array}$ & 38 & 2,05 & 1,06 \\
\hline $\begin{array}{c}\text { The teacher prompt students make group } \\
\text { work. }\end{array}$ & 38 & 2,00 & 1,02 \\
\hline $\begin{array}{c}\text { The teacher cares to use body language } \\
\text { during communication. }\end{array}$ & 38 & 1,97 & 0,91 \\
\hline $\begin{array}{c}\text { The teacher can easily attract students' } \\
\text { attention toward course. }\end{array}$ & 38 & 1,92 & 0,85 \\
\hline $\begin{array}{c}\text { The teacher provides multidirectional } \\
\text { communication. }\end{array}$ & 38 & 1,84 & 0,82 \\
\hline The teacher can easily motivate students. & 38 & 1,73 & 0,89 \\
\hline $\begin{array}{c}\text { The teacher pays attention individual } \\
\text { differences. }\end{array}$ & 38 & 1,71 & 0,78 \\
\hline
\end{tabular}

Table 8. The classroom management problems in technology-supported classrooms in terms of "relationship layout dimension" of classroom management

\begin{tabular}{|c|c|c|c|}
\hline & $\mathbf{N}$ & Mean & SD \\
\hline The teacher can easily motivate students. & 41 & 3,48 & 0,59 \\
\hline $\begin{array}{c}\text { The teacher can easily attract students' } \\
\text { attention toward course. }\end{array}$ & 41 & 3,39 & 0,66 \\
\hline $\begin{array}{l}\text { The teacher gives the students the right to } \\
\text { speak. }\end{array}$ & 41 & 3,31 & 1,05 \\
\hline $\begin{array}{l}\text { The teacher can provide the participation of } \\
\text { the students. }\end{array}$ & 41 & 3,12 & 0,74 \\
\hline $\begin{array}{l}\text { The teacher cares to use body language } \\
\text { during communication. }\end{array}$ & 41 & 3,07 & 0,72 \\
\hline $\begin{array}{l}\text { The teacher provides multidirectional } \\
\text { communication. }\end{array}$ & 41 & 2,95 & 0,73 \\
\hline $\begin{array}{c}\text { The teacher is walking all over the } \\
\text { classroom. }\end{array}$ & 41 & 2,87 & 0,81 \\
\hline $\begin{array}{l}\text { The teacher uses her/his voice as everyone } \\
\text { can hear in the classroom. }\end{array}$ & 41 & 2,65 & 0,71 \\
\hline $\begin{array}{c}\text { The teacher prompts students do group } \\
\text { work. }\end{array}$ & 41 & 2,36 & 0,85 \\
\hline $\begin{array}{l}\text { The teacher stands at the same point in the } \\
\text { classroom and does not move. }\end{array}$ & 41 & 2,53 & 0,74 \\
\hline Students behave shy. & 41 & 1,95 & 0,77 \\
\hline $\begin{array}{l}\text { The teacher pays attention individual } \\
\text { differences. }\end{array}$ & 41 & 1,97 & 0,76 \\
\hline $\begin{array}{c}\text { The teacher makes eye contact with } \\
\text { students. }\end{array}$ & 41 & 1,73 & 1,07 \\
\hline
\end{tabular}


Table 8 shows that in technology-supported classrooms teachers can motivate students $(\bar{X}=3,48)$ and easily attract their attention to the course $(\bar{X}=3,39)$. Using technological equipment in education attracts students' attention to the course and by this way teachers can motivate students more easily. This situation can be counted as one of the reasons of an increase in student participation $(\bar{X}=3,12)$. Students sometimes behave shy $(\overline{\mathrm{X}}=1,95)$ in technology-supported classrooms and the teachers in these classrooms can have problems in making eye contact with students $(\bar{X}=1,73)$. The reasons of this situation can be teachers' not changing the methods and techniques in the classrooms and not caring about individual differences.

Findings and comments about the fifth sub problem "according to candidate teachers' views, the classroom management problems of middle school $6^{\text {th }}$ and $7^{\text {th }}$ grade teachers in traditional and technology-supported classrooms in terms of behavior arrangement dimension of classroom management".

Table 9. The classroom management problems in classrooms without technology (traditional classrooms)in terms of "behavior arrangement dimension" of classroom management

\begin{tabular}{|c|c|c|c|}
\hline & N & Mean & SD \\
\hline Students walk needlessly in classroom. & 38 & 3,31 & 0,96 \\
\hline $\begin{array}{c}\text { Students show aggressive behaviors to each } \\
\text { other. }\end{array}$ & 38 & 2,60 & 0,97 \\
\hline $\begin{array}{c}\text { Students perform assigned tasks. } \\
\text { ctudents disturb their friends during the } \\
\text { course. }\end{array}$ & 38 & 2,42 & 0,82 \\
\hline $\begin{array}{c}\text { The teacher can provide positive classroom } \\
\text { environment. }\end{array}$ & 38 & 2,28 & 0,89 \\
\hline Students talk without permission. & 38 & 2,26 & 0,86 \\
\hline Students do homework on time. & 38 & 2,24 & 0,91 \\
\hline $\begin{array}{c}\text { Students come to course on time. } \\
\text { Students are disposed to use course } \\
\text { equipment. }\end{array}$ & 38 & 2,21 & 1,07 \\
\hline $\begin{array}{c}\text { Students care to obey classroom rules. } \\
\text { place in classroom. }\end{array}$ & 38 & 2,21 & 1,04 \\
\hline $\begin{array}{c}\text { The teacher can overcome many events take } \\
\text { she }\end{array}$ & 38 & 1,97 & 0,75 \\
\hline
\end{tabular}

When classroom management problems in traditional classroom are examined in terms of behavior arrangement dimension, it is found that the biggest problem is students' walk needlessly in the classroom $(\bar{X}=3,31)$. Table 9 shows that students usually show aggressive behaviors to each other $(\bar{X}=2,60)$. In addition to that it can be seen that students sometimes talk without permission $(\bar{X}=2,26)$, disturb their friends during the course $(\bar{X}=2,28)$. Even if students sometimes care to obey classroom rules $(\bar{X}=2,15)$, the average is low. Besides, results show that teachers have difficulty in overcoming many events that take place in classrooms $(\overline{\mathrm{X}}=1,97)$. In traditional classrooms students act numerous negative behaviors and teachers have difficulty coping with these problems.

Table 10. The classroom management problems in technology-supported classrooms in terms of "behavior arrangement dimension" of classroom management

\begin{tabular}{|c|c|c|c|}
\hline & $\mathbf{N}$ & Mean & SD \\
\hline $\begin{array}{c}\text { The teacher can provide positive classroom } \\
\text { environment. }\end{array}$ & 41 & 3,21 & 0,68 \\
\hline $\begin{array}{c}\begin{array}{c}\text { Students are disposed to use course } \\
\text { equipment. }\end{array} \\
\end{array}$ & 41 & 3,09 & 0,80 \\
\hline Students perform assigned tasks. & 41 & 2,97 & 0,56 \\
\hline Students care to obey classroom rules. & 41 & 2,85 & 0,47 \\
\hline Students do homework on time. & 41 & 2,65 & 0,82 \\
\hline Students come to course on time. & 41 & 2,43 & 0,69 \\
\hline $\begin{array}{l}\text { Students show aggressive behaviors to each } \\
\text { other. }\end{array}$ & 41 & 2,41 & 0,74 \\
\hline $\begin{array}{l}\text { The teacher can overcome many events } \\
\text { take place in classroom. }\end{array}$ & 41 & 2,31 & 0,52 \\
\hline $\begin{array}{l}\text { Students disturb their friends during the } \\
\text { course. }\end{array}$ & 41 & 2,24 & 0,61 \\
\hline Students walk needlessly in classroom. & 41 & 2,00 & 0,59 \\
\hline Students talk without permission. & 41 & 1,97 & 0,52 \\
\hline
\end{tabular}

Results show that in technology-supported classrooms teachers usually can provide positive classroom environment $(\bar{X}=3,21)$. Also it seems that students usually perform assigned tasks $(\bar{X}=2,97)$ and care to obey classroom rules $(\bar{X}=2,85)$. Even the students exhibit undesired behaviors, the average points are low. Students sometimes disturb their friends during the course $(\bar{X}=2,24)$, walk needlessly in the classroom $(\bar{X}=2,00)$ and talk without permission $(\bar{X}=1,97)$. Even if the use of technology causes decrease in some behavioral problems, many problems still continue.

Findings and comments concerning the sixth sub problem "according to candidate teachers' views, difference in the classroom management problems of middle school $6^{\text {th }}$ and $7^{\text {th }}$ grade teachers in traditional and technology-supported classrooms in terms of physical organization, plans and programs, time management, relationship layout and behavior regulation dimensions of classroom management. 
Table 11. Differences in classroom management problems with regard to physical organization dimension in traditional and technology-supported classrooms

\begin{tabular}{|c|c|c|c|c|}
\hline & Group & Mean & t & $\mathbf{p}$ \\
\hline \multirow{2}{*}{ The class is at the ideal temperature. } & Traditional Classrooms & 2,36 & \multirow{2}{*}{$-1,40$} & \multirow{2}{*}{0,166} \\
\hline & Technology-supported Classrooms & 2,65 & & \\
\hline \multirow{2}{*}{ Lighting conditions of classroom is proper for education. } & Traditional Classrooms & 3,44 & \multirow{2}{*}{9,90} & \multirow{2}{*}{0,000} \\
\hline & Technology-supported Classrooms & 1,65 & & \\
\hline \multirow{2}{*}{ The noise level in the class is normal. } & Traditional Classrooms & 2,26 & \multirow{2}{*}{$-2,22$} & \multirow{2}{*}{0,030} \\
\hline & Technology-supported Classrooms & 2,65 & & \\
\hline \multirow{2}{*}{ Cleaning of class is supplied. } & Traditional Classrooms & 2,47 & \multirow{2}{*}{$-0,48$} & \multirow{2}{*}{0,627} \\
\hline & Technology-supported Classrooms & 2,58 & & \\
\hline \multirow{2}{*}{ Equipment in class is sufficient } & Traditional Classrooms & 2,21 & \multirow{2}{*}{$-4,54$} & \multirow{2}{*}{0,000} \\
\hline & Technology-supported Classrooms & 3,07 & & \\
\hline \multirow{2}{*}{ The appearance of class is aesthetic. } & Traditional Classrooms & 2,15 & \multirow{2}{*}{$-3,39$} & \multirow{2}{*}{0,001} \\
\hline & Technology-supported Classrooms & 2,92 & & \\
\hline \multirow{2}{*}{ The ventilation of class is sufficient. } & Traditional Classrooms & 2,31 & \multirow{2}{*}{$-3,00$} & \multirow{2}{*}{0,004} \\
\hline & Technology-supported Classrooms & 2,97 & & \\
\hline
\end{tabular}

$\mathrm{P}<0,050$

Some differences have been found between traditional and technology-supported classrooms in terms of physical variables. Technology-supported classes are darker than traditional classrooms $(t=-9,90)$. The reason for that can be the use of tools to inhibit the light coming from the outside in technology-supported classrooms. And also it has been found that technology-supported classrooms have more aesthetic appearance $(t=-3,39)$ and are more sufficient in terms of equipment $(\mathrm{t}=-4,54)$. Furthermore, the results show that the ventilation of technology-supported classrooms is more sufficient than the traditional classroom ventilation. There is no significant difference between two groups in terms of cleanliness and temperature of the classroom.

Table 12. Differences in classroom management problems with regard to plans and programs dimension in traditional and technology-supported classrooms

\begin{tabular}{|c|c|c|c|c|}
\hline & Group & Mean & t & $\mathbf{P}$ \\
\hline \multirow{2}{*}{ The teacher plans classroom activities in advance. } & Traditional Classrooms & 2,55 & \multirow{2}{*}{$-1,08$} & \multirow{2}{*}{0,280} \\
\hline & Technology-supported Classrooms & 2,78 & & \\
\hline \multirow{2}{*}{$\begin{array}{l}\text { The teacher changes method and techniques used in } \\
\text { classroom. }\end{array}$} & Traditional Classrooms & 1,71 & \multirow{2}{*}{$-7,46$} & \multirow{2}{*}{0,114} \\
\hline & Technology-supported Classrooms & 1,95 & & \\
\hline \multirow{2}{*}{$\begin{array}{l}\text { The teacher makes equipment ready before starting the } \\
\text { course. }\end{array}$} & Traditional Classrooms & 1,84 & \multirow{2}{*}{$-3,01$} & \multirow{2}{*}{0,004} \\
\hline & Technology-supported Classrooms & 2,34 & & \\
\hline
\end{tabular}

$\mathrm{P}<0,050$

There is no significant difference between technology-supported classrooms and traditional classrooms in terms of planning activities $(t=-1,08)$. In both groups it is seen that teachers sometimes make plans. Both in technology-supported and traditional classrooms teachers always use the same methods. Any significant difference between these two groups in terms of changing the methods and techniques used in the classroom has not been found $(t=-7,46)$. But it has been observed that in technology-supported classrooms teachers make equipment ready before starting the course more often than the teachers do in traditional classrooms.

Table 13. Differences in classroom management problems with regard to time management dimension in traditional and technology-supported classrooms

\begin{tabular}{|c|c|c|c|c|}
\hline & Group & Mean & $\mathbf{t}$ & $\mathbf{P}$ \\
\hline \multirow{2}{*}{$\begin{array}{l}\text { The teacher can use time effectively during the } \\
\text { course. }\end{array}$} & Traditional Classrooms & 2,36 & \multirow{2}{*}{$-4,507$} & \multirow{2}{*}{0,000} \\
\hline & Technology-supported Classrooms & 3,24 & & \\
\hline \multirow{2}{*}{$\begin{array}{l}\text { The teacher can use course equipment sufficiently } \\
\text { and effectively. }\end{array}$} & Traditional Classrooms & 2,28 & \multirow{2}{*}{$-6,083$} & \multirow{2}{*}{0,000} \\
\hline & Technology-supported Classrooms & 3,29 & & \\
\hline \multirow{2}{*}{$\begin{array}{l}\text { Classroom environment is an environment that } \\
\text { students want to spend most of their time. }\end{array}$} & Traditional Classrooms & 1,89 & \multirow{2}{*}{$-4,72$} & \multirow{2}{*}{0,000} \\
\hline & Technology-supported Classrooms & 2,80 & & \\
\hline \multirow{2}{*}{$\begin{array}{l}\text { The teacher can provide vitality during the course, } \\
\text { does not bore students. }\end{array}$} & Traditional Classrooms & 2,00 & \multirow{2}{*}{$-6,075$} & \multirow{2}{*}{0,000} \\
\hline & Technology-supported Classrooms & 3,02 & & \\
\hline
\end{tabular}


Table 13 shows that there is a significant difference $(t=-4,507)$ between traditional classrooms and technology-supported classrooms in terms of using time effectively during the course. This means that in technology-supported classrooms teachers use time more effectively during the course. It seems that in technology-supported classrooms teachers use course equipment more effectively $(\mathrm{t}=-6,083)$. By this way, these teachers provide vitality during the course and do not bore students $(\mathrm{t}=-6,075)$. This can be the reason that makes students want to spend more time $(\mathrm{t}=-4,72)$ in technology-supported classrooms.

Table 14. Differences in classroom management problems with regard to relationship layout dimension in traditional and technology-supported classrooms.

\begin{tabular}{|c|c|c|c|c|}
\hline & Group & Mean & $\mathbf{t}$ & $\mathbf{P}$ \\
\hline \multirow{2}{*}{ The teacher can easily motivate students. } & Traditional Classrooms & 1,73 & \multirow{2}{*}{$-10,182$} & \multirow{2}{*}{0,000} \\
\hline & Technology-supported Classrooms & 3,48 & & \\
\hline \multirow{2}{*}{$\begin{array}{c}\text { The teacher can easily attract students attention } \\
\text { toward course. }\end{array}$} & Traditional Classrooms & 1,92 & \multirow{2}{*}{$-8,502$} & \multirow{2}{*}{0,000} \\
\hline & Technology-supported Classrooms & 3,39 & & \\
\hline \multirow{2}{*}{$\begin{array}{l}\text { The teacher provides multidirectional } \\
\text { communication. }\end{array}$} & Traditional Classrooms & 1,84 & \multirow{2}{*}{$-6,282$} & \multirow{2}{*}{0,000} \\
\hline & Technology-supported Classrooms & 2,95 & & \\
\hline \multirow{2}{*}{ The teacher makes eye contact with students. } & Traditional Classrooms & 2,00 & \multirow{2}{*}{2,105} & \multirow{2}{*}{0,065} \\
\hline & Technology-supported Classrooms & 1,73 & & \\
\hline \multirow{2}{*}{ The teacher gives students the right to speak. } & Traditional Classrooms & 2,36 & \multirow{2}{*}{$-4,641$} & \multirow{2}{*}{0,000} \\
\hline & Technology-supported Classrooms & 3,31 & & \\
\hline \multirow{2}{*}{$\begin{array}{l}\text { The teacher can provide the participation of the } \\
\text { students. }\end{array}$} & Traditional Classrooms & 2,23 & \multirow{2}{*}{$-5,000$} & \multirow{2}{*}{0,000} \\
\hline & Technology-supported Classrooms & 3,12 & & \\
\hline \multirow{2}{*}{$\begin{array}{l}\text { The teacher stands at the same point in the } \\
\text { classroom and does not move. }\end{array}$} & Traditional Classrooms & 2,05 & \multirow{2}{*}{$-2,325$} & \multirow{2}{*}{0,023} \\
\hline & Technology-supported Classrooms & 2,53 & & \\
\hline \multirow{2}{*}{ The teacher prompt students make group work. } & Traditional Classrooms & 2,00 & \multirow{2}{*}{$-1,915$} & \multirow{2}{*}{0,060} \\
\hline & Technology-supported Classrooms & 2,36 & & \\
\hline \multirow{2}{*}{$\begin{array}{l}\text { The teacher uses her/his voice as everyone can hear } \\
\text { in the classroom. }\end{array}$} & Traditional Classrooms & 2,57 & \multirow{2}{*}{$-3,396$} & \multirow{2}{*}{0,0694} \\
\hline & Technology-supported Classrooms & 2,65 & & \\
\hline \multirow{2}{*}{ The teacher is walking all over the classroom. } & Traditional Classrooms & 2,68 & \multirow{2}{*}{$-1,221$} & \multirow{2}{*}{0,226} \\
\hline & Technology-supported Classrooms & 2,87 & & \\
\hline \multirow{2}{*}{$\begin{array}{l}\text { The teacher cares to use body language during } \\
\text { communication. }\end{array}$} & Traditional Classrooms & 1,81 & \multirow{2}{*}{$-4,576$} & \multirow{2}{*}{0,000} \\
\hline & Technology-supported Classrooms & 2,46 & & \\
\hline 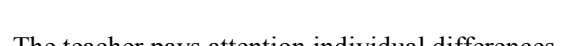 & Traditional Classrooms & 1,71 & 1482 & 0142 \\
\hline 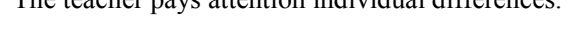 & Technology-supported Classrooms & 1,97 & $-1,403$ & 0,142 \\
\hline 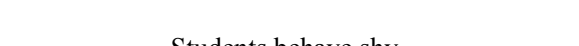 & Traditional Classrooms & 2,60 & 4. 724 & 0000 \\
\hline 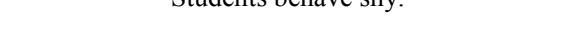 & Technology-supported Classrooms & 1,95 & $-4, / 24$ & 0,000 \\
\hline $\mathrm{P}<0,050$ & & & & \\
\hline
\end{tabular}

In technology-supported classrooms teachers can motivate students $(\mathrm{t}=-10,182)$ and attract students' attention to the course $(t=-8,502)$ more easily than in traditional classrooms. In technology-supported classrooms, teachers care to use body language during communication $(t=-4,576)$, give the students the right to speak $(t=-4,641)$ and can provide the participation of the students $(t=-5,000)$. But in technology-supported classrooms it is seen that students behave shy $(t=-4,724)$. The reason may be that students are not familiar with this equipment or they have obstacles in communication with their teachers. Likewise, in technology-supported classrooms teachers usually stand at the same point in the classroom and does not move $(\mathrm{t}=-2,325)$. The source of this problem may be that teachers do not know how to use technological equipment in the direction of their aims. 
Table 15. Differences in classroom management problems with regard to behavior arrangement dimension in traditional and technology-supported classrooms.

\begin{tabular}{|c|c|c|c|c|}
\hline & Group & Mean & $\mathbf{t}$ & $\mathbf{P}$ \\
\hline \multirow{2}{*}{$\begin{array}{l}\text { The teacher can provide positive classroom } \\
\text { environment. }\end{array}$} & Traditional Classrooms & 2,28 & \multirow{2}{*}{$-5,250$} & \multirow{2}{*}{0,000} \\
\hline & Technology-supported Classrooms & 3,21 & & \\
\hline \multirow{2}{*}{$\begin{array}{l}\text { The teacher can overcome many events take place } \\
\text { in classroom. }\end{array}$} & Traditional Classrooms & 1,97 & \multirow{2}{*}{$-1,785$} & \multirow{2}{*}{0,078} \\
\hline & Technology-supported Classrooms & 2,31 & & \\
\hline \multirow{2}{*}{ Students do homework on time. } & Traditional Classrooms & 2,24 & \multirow{2}{*}{$-1,693$} & \multirow{2}{*}{0,034} \\
\hline & Technology-supported Classrooms & 2,65 & & \\
\hline \multirow{2}{*}{ Students show aggressive behaviors to each other. } & Traditional Classrooms & 2,60 & \multirow{2}{*}{3,249} & \multirow{2}{*}{0,328} \\
\hline & Technology-supported Classrooms & 2,41 & & \\
\hline \multirow{2}{*}{ Students perform assigned tasks. } & Traditional Classrooms & 2,42 & \multirow{2}{*}{$-3,447$} & \multirow{2}{*}{0,001} \\
\hline & Technology-supported Classrooms & 2,97 & & \\
\hline \multirow{2}{*}{ Students behave shy. } & Traditional Classrooms & 2,60 & \multirow{2}{*}{3,029} & \multirow{2}{*}{0,004} \\
\hline & Technology-supported Classrooms & 1,95 & & \\
\hline \multirow{2}{*}{ Students care to obey classroom rules. } & Traditional Classrooms & 2,34 & \multirow{2}{*}{$-4,254$} & \multirow{2}{*}{0,010} \\
\hline & Technology-supported Classrooms & 2,85 & & \\
\hline \multirow{2}{*}{ Students walk needlessly in classroom. } & Traditional Classrooms & 3,31 & \multirow{2}{*}{7,258} & \multirow{2}{*}{0,000} \\
\hline & Technology-supported Classrooms & 2,00 & & \\
\hline \multirow{2}{*}{ Students talk without permission. } & Traditional Classrooms & 2,26 & \multirow{2}{*}{2,852} & \multirow{2}{*}{0,052} \\
\hline & Technology-supported Classrooms & 1,97 & & \\
\hline \multirow{2}{*}{ Students come to course on time. } & Traditional Classrooms & 2,21 & \multirow{2}{*}{$-1,180$} & \multirow{2}{*}{0,243} \\
\hline & Technology-supported Classrooms & 2,43 & & \\
\hline \multirow{2}{*}{ Students are disposed to use course equipment. } & Traditional Classrooms & 2,21 & \multirow{2}{*}{$-4,215$} & \multirow{2}{*}{0,000} \\
\hline & Technology-supported Classrooms & 3,09 & & \\
\hline \multirow{2}{*}{ Students disturb their friends during the course. } & Traditional Classrooms & 2,28 & 0406 & 0696 \\
\hline & Technology-supported Classrooms & 2,24 & 0,406 & 0,686 \\
\hline
\end{tabular}

$\mathrm{P}<0,050$

It has been found out that teachers have less trouble in providing positive classroom environment in technology-supported classrooms, compared to traditional classrooms $(t=-5,250)$. Besides, it is seen that in technology-supported classrooms students usually perform assigned tasks $(\mathrm{t}=-3,447)$ and do homework on time $(t=-1,693)$. The most important reason for this may be that students are more interested in technology and they prefer to prepare their homework faster by using technology. In technology-supported classrooms students behave less shy in comparison to traditional classrooms $(t=3,029)$. But there is no significant difference between two groups regarding the averages of showing aggressive behaviors to each other $(t=3,249)$, averages of talking without permission $(t=2,852)$ and disturbing their friends during the course $(\mathrm{t}=0,406)$. There are some similarities in behavior problems that occur in technology-supported and traditional classrooms. Using technology in the classrooms did not cause any change in frequency of occurrence of many undesired behaviors. That the teachers have difficulties in managing the technology or they prefer to deal with the problems they face in the use of technology may be the reason for negative behaviors.

\section{Conclusions and Recommendations}

Research results show that problems, which occur in terms of some dimensions of classroom management in traditional classrooms, occur less in technology-supported classrooms. But one of the important findings of the research is that the use of technology in classrooms brings about some new problems in terms of some dimensions of classroom management.

Hence, organizing education environments by considering some criteria will both increase the efficiency of education and facilitate achieving the goals intended. When evaluated in terms of physical variables, using technology makes the appearance of classrooms more aesthetic. The number of instruments used in the classrooms increase depending on the use of technology. By this way, technologic equipment change the classical appearance of classrooms. Using technology in classrooms affects students' desire to spend more time in classrooms. But in technology-supported classrooms brightness ratio has found to be low in comparison to traditional classrooms because of the obligation to prevent light reflections. Lighting of the 
classroom is an important factor for increasing the qualification of education. Taking this fact into account, in technology-supported classrooms curtains must be suitable for multipurpose use, architectural arrangements must be done considering the convenience of size and colors of windows and angle of incidence of light and lightening equipment must be controlled by more than one switch. In the research conducted by Cengizhan [19] it was found that in technology-supported classrooms no change for settlement arrangement could be made, classrooms were dark, lightening tools which were at the windows side, were controlled by a second switch only in the $\% 36$ percent of the classrooms, and \%64 percent of classrooms had just one switch.

When it is evaluated in terms of plans and programs dimension of classroom management, results show that routines and stability in traditional classrooms continue to be exist in technology-supported classrooms too and teachers do not change methods they use during the course. Whereas using technology in education requires new learningteaching techniques instead of classical methods. Technology-supported environments provide many opportunities for students such as making courses more attractive [20], making positive contribution for motivation, supporting teaching learning process, providing more participation in learning activities [21;22;23], contributing positively to interactive interaction [24], giving opportunity to take action on ready materials [25]. Despite these opportunities, teachers that use technology-supported environments still use more traditional methods. And this is an important barrier for increasing the qualification of education.

Students feel bored less in technology-supported classrooms. These classrooms are the places where students spend their times. And time is used more efficiently in technology-supported classrooms during the course. Course equipment is the greatest helpers of teachers; when they are used effectively, they provide advantages to teachers in terms of time management. It has also been found in researches of Averis, Door, Glover and Miller [26], Beauchamp, Jones, Kennewell and Tanner [27], Kayaduman, Sarıkaya and Seferoğlu [28], Bulut and Koçoğlu [29] that technology-supported environments make facilitating effect to the visual aspect of education, interactive interaction, do not bore students, provide time savings and help better and easier understanding. When it is considered that teachers can have more time to discover students' creativities and abilities, spend long and qualified time with students through effective time management [30] and effective time management provides economy for school management, teacher and students [31], it can be said that technology-supported classrooms make important contributions in terms of time management.

Using technology in education, decreases monotony by making the classroom environment enjoyable and funny. Teachers can motivate students and attract students' attention to the course more easily. By this way, they can provide vitality and attendance to the course and do not bore students. There is a parallelism with research results of Ermiş [32] in terms of those points; technology-supported environments contribute to students' motivation in a positive way, encourage teaching and learning process and provide more attendance to learning activities. In their researches Averis, Door, Glover ve Miller[26]Beauchamp, Jones, Kennewell ve Tanner [27], Kayaduman, Sarıaya ve Seferoğlu [28], Bulut ve Koçoğlu [29] also got similar results about attendance, increase in communication and attracting students attention to course more easily. Also, in technology-supported classrooms students behave shy, teachers usually stand at the same point, do not move around the classroom and make presentations by looking at the slides on the interactive board. And these result as an important barrier for formation of relationship layout.

It has not been found any decrease in the frequency of occurrence of undesired behaviors in technology-supported classrooms. It has not been found any significant difference between the two groups. Decrease at shyness emotions of students is one of the advantages of technology-supported environments. The reason may be that teachers can motivate students more easily. Moreover it has been found that in technology-supported classrooms students are more willing to perform assigned tasks and do homework since they are concentric with technology and they are willing to benefit from technology in the classroom environment.

While equipping teaching environments with technology, efforts to make use of its advantages in education should be regarded. Furnishing classrooms with technological equipment of education will affect just physical variables. Despite the fact that physical equipment is effective, teachers should be conscious while using technology in classroom environments. Using technology effectively does not mean just having full knowledge of its hardware; it means using that hardware in the classroom environment in a manner that is convenient for existing conditions or in a manner that develops the conditions. The teacher should use technology to constitute a positive classroom environment. If the teacher uses technology in classroom environment in a perfunctory manner, this situation will become monotonous and will cause new classroom management problems. This situation will not be different from that of in a traditional classroom.

According to the research results, the following suggestions can be given;

1. When equipping classrooms with technology, arrangements should be done by considering physical variables of classroom management.

2. Teachers should be prompt to use the new methods and techniques to be used in technology-supported environments in their classrooms.

3. Teachers should be educated in the pre-service education as having acquired competence in the preparation of visual materials to contribute to time management in class. 
4. Teachers should be trained in terms of effective presentation preparation and presentation techniques.

5. Teachers should be prompt to use technology effectively in the classrooms.

6. Teachers should be educated regularly on educational technology.

\section{REFERENCES}

[1] Kılıç, E. , Özdemir, S.(2006). Bilgi Teknoloji Sınıflarının Dağılımı ve Sürekliliğinin Sağlanması ile İlgili Çalışmaların Değerlendirilmesi.Gazi Üniversitesi Türk Eğitim Bilimleri Dergisi. Cilt 4 Sayı 2. Ankara.

[2] Bal, H. Keleş, M. ve Erbil, O. (1999). Eğitimde Teknoloji Klavuzu.Milli Eğitim Bakanlığı Eğitim Araştırma ve Geliştirme Dairesi Başkanlığı. Ankara.

[3] Uşun, S. (2003). Eğitim ve Öğretimde Bilgisayarların Yararları ve Bilgisayarlardan Yararlanmada Önemli Rol Oynayan Etkenlere İliş̧kin Öğrenci Görüşleri. Kastamonu Eğitim Fakültesi Dergisi. Cilt 11 No 2 Sayfa 367-378

[4] İşman, A. (2001). Bilgisayar ve Eğitim. Sakarya Üniversitesi Eğitim Fakültesi Dergisi, Sayı 2 Sakarya.

[5] Yalın, H.İ (2017). Öğretim Teknolojileri ve Materyal Geliştirme. 29. Baskı. Nobel Yayıncılık. Ankara.

[6] Şimşek, N. (2002). Derste Eğitim Teknolojisi Kullanımı. Nobel Yayın Dağıtım. 2. Baskı. Ankara.

[7] İşman, A. (2005). Öğretim Teknolojileri ve Materyal Geliştirme. Sempati Yayınları 2. Baskı. Ankara.

[8] Seferoğlu, S. S. (2006). Öğretim Teknolojileri ve Materyal Tasarımı. Pegem Yayıncılık 3. Baskı. Ankara.

[9] Başar, H. (2014). Sınıf yönetimi, 19. Baskı, Anı Yayıncılık. Ankara.

[10] Erden, M.(2014). Sınıf yönetimi. İstanbul. Alkım Yayınları.

[11] Şenol Y. Aksu M. "A clinical supervision and peer consultation practice in Problem based learning process.", IOJET, cilt.2, ss.2-10, 2015

[12] Adair, J ve Talbot A. (2004). Zaman yönetimi. (Çev. Güngör Bengü). Öteki Yayınevi. Ankara.

[13] Başaran, İ.E, (2005) Yönetimde İnsan İlişkileri. Pegem Akademi Yayıncılık. Ankara.

[14] Karagözoğlu, G. (2001).İletişimin Değerlendirilmesi. Eğitim Yönetiminde Denetleme ve Değerlendirme Sempozyumu, Eğitim Bilimleri Fakültesi Yayınları. No:147.Ankara.

[15] Ataman, A. (2003). Sınıfta İletişimde Karşılaşılan Problemler. Gazi Üniversitesi. Türk Eğitim Bilim Dergisi. Cilt 1 Say1 3. Ankara.

[16] Kıncal,R. (2015). Bilimsel Araştırma Yöntemleri. Nobel yayıncılık. 4. Baskı Ankara.
[17] Karasar, N. (2005). Bilimsel araştırma yöntemleri, Ankara: Nobel Yayınları.

[18] Özata, O. (2004).Kdz. Ereğli İlköğretim Okulları Öğretmenlerinin Sınıf Yönetimindeki Yeterlikleri. Yayınlanmamış Yüksek Lisan Tezi.Zonguldak Karaelmas Üniversitesi. Bilimler Enstitüsü.

[19] Cengizhan, C. , (2003). İstanbul Anadolu Yakası İlköğretim Okullarındaki Bilgisayar Labaratuarlarının Yerleşim Planları Ve Ergonomik Kriterler Açısından İncelenmesi.

[20] Ateş, M. (2010). Ortaöğretim Coğrafya Derslerinde Etkileşimli Tahta Kullanımı. Marmara Coğrafya Dergisi. Sayı 22. $409-427$

[21] Beauchamp, G. ve Kennewell, S. (2007). The Features Of Interactive Whiteboards and Their Influence On Learning. Learning, Media and Technology, 32(3), 227-241.

[22] Akbaş, O. ve Pektaş, H. (2011). The Effects Of Using An Interactive Whiteboard On The Academic Achievement Of University Students. Asia-Pacific Forum On Science Learning \& Teaching. 12 (2), 1-19.

[23] Altınçelik, B. (2009). İlköğretim Düzeyinde Öğrenmede Kalıcılığı ve Motivasyonu Sağlaması Yönünden Akı1lı Tahtaya İlişkin Öğretmen Görüşleri. Yüksek Lisans Tezi. Sakarya Ün. Üniversitesi. Sosyal Bilimler Enstitüsü. Sakarya.

[24] Herbert, M. (2012). Whiteboards Engage Autistic Students in Social Learning. District Administration, 48(3), 44.

[25] Demirli, C. ve Türel, Y. K. (2010). Instructional Interactive Whiteboard Materials: Designers'Perspectives, Procedia Social and Behavioral Sciences,9, 1437-1442.

[26] Averis, D. Door, V. Glover, D. ve Miller, D.(2007). The Evolution Of An Effective Pedagogy For Teachers Using The İnteractive Whiteboard And Modern Languages: An Empiric Analysis From The Secondary Sectors. Learning, Media and Technology. 32(1).

[27] Beauchamp, G., Jones, S., Kennewell, S. ve Tanner, H. (2008). Analysing The Use Of İnteractive Technology To İmplement Interactive Teaching. Journal of Computer Assisted Learning, $34,61-73$.

[28] Kayaduman, H., Sarıkaya, M. ve Seferoğlu, S. S. (2011).Eğitimde FATİH Projesinin Öğretmenlerin Yeterlik Durumları Açısından İncelenmesi. XIII. Akademik Bilişim Konferans1 (AB11),İnönü Üniversitesi, Malatya.

[29] Bulut, G. ve Koçoğlu, E. (2012). Sosyal Bilgiler Öğretmenlerinin Akıllı Tahta Kullanımına İlişkin Görüşleri (Diyarbakır İli Örneği).Dicle Üniversitesi Ziya Gökalp Eğitim Fakültesi Dergisi, 19, 242-258.

[30] Taş, S. (2010). İlköğretim Okullarında Sınıfta Zaman Kaybettiren Etkinlikler. Süleyman Demirel Üniversitesi Sosyal Bilimler Enstitüsü Dergisi.

[31] Erkılıç, T.A. (2006). Zaman Yönetimi. Etkili Sınıf Yönetimi. (Edt. Hüseyin Kıran). s.128-129 An1 Yayınc1lık. Ankara.

[32] Ermiş, U. F. (2012). Fen ve Teknoloji Dersinde Etkileşimli Tahta Kullanımının Akademik Başarı Ve Öğrenci Motivasyonuna Etkisi. Yüksek Lisans Tezi. Gazi Üniversitesi Eğitim Bilimleri Enstitüsü. Ankara. 